\title{
Exploring the biochemical, haemostatic and toxinological aspects of mapanare dry-tail (Porthidium lansbergii rozei) snake's venom causing human accidents in Eastern Venezuela
}

\author{
María E. Girón ${ }^{1}$, María I. Ramos ${ }^{1}$, Luisneidys Cedeño ${ }^{1}$, Axl Carrasquel, \\ Elda E. Sánches ${ }^{2}$, Luis F. Navarrete ${ }^{1}$ and Alexis Rodríguez-Acosta ${ }^{1}$ \\ ${ }^{1}$ Laboratorio de Inmunoquímica y Ultraestructura, Instituto Anatómico \\ "José Izquierdo", Facultad de Medicina, Universidad Central de Venezuela, Caracas, \\ Venezuela. \\ ${ }^{2}$ National Natural Toxins Research Center (NTRC), Texas A\&M University-Kingsville, \\ MSC 158, Kingsville, TX, USA.
}

Key words: Porthidium lansbergii rozei; fibrinolysis; haemorrhages; lethality; venom.

Abstract. Porthidium lansbergii rozei (Pl.rozei) is a snake species belonging to the Venezuelan ophidian-fauna causing relatively frequent human accidents. This study has been developed to enrich the medical information about this snake's accident, which is often handled with difficulties due to the ignorance about its toxic activities. This work has studied the biochemical and toxinological characteristics of the P.l.rosei venom. The objective was to determine its biochemical characteristics, including protein content determination, electrophoretic and P.l.rozei chromatographic profile. The toxinological and enzymatic functions, comprised lethality $\left(\mathrm{LD}_{50}\right)$, haemorrhagic (MHD), myotoxic, coagulant, oedematising, proteolytic, fibrinogenolytic, fibrinolytic, anticoagulant, and phospholipase activities and crude venom recognition by the Venezuelan polyvalent antivenom (PAOS). The venom induced haemorrhagiic, myotoxic, anticoagulant, fibrinolytic, fibrinogenolytic, and phospholipase $\mathrm{A}_{2}$ activities in mice; the $\mathrm{LD}_{50}$ was not established even though the doses tested expand the different lethal doses reported in previous studies. The venom induced a dose-dependent oedema up to the dose of $4 \mu \mathrm{g}$, corresponding to 27.91\%. In conclusion, the studied venom presented a haemostatic, toxinological, and enzymatic biochemical profile similar to the one described for specimens of the Porthidium genus. However, there were evident quantitative variations in their different activities, offering new evidence of the intra-species variations that exists in the different snake families. These variations must be accounted for appropriate clinical management.

Corresponding author: Alexis Rodriguez-Acosta. Laboratorio de Inmunoquímica y Ultraestructura, Instituto Anatómico "José Izquierdo", Facultad de Medicina, Universidad Central de Venezuela, Caracas, Venezuela. Email: rodriguez-acosta1946@yahoo.es. 


\section{Explorando los aspectos bioquímicos, hemostáticos y toxinológicos del veneno de la serpiente mapanare rabo-seco (Porthidium lansbergii rozei) que causa accidentes humanos en el oriente de Venezuela}

Invest Clin 2018; 59 (3): 260 - 277

Palabras clave: Porthidium lansbergiii rozei; fibrinólisis; hemorragias; letalidad; veneno.

Resumen. Porthidium lansbergii rozei (P.l.rozei) es una especie de serpiente perteneciente a la ofidio-fauna venezolana, que causa accidentes humanos relativamente frecuentes. Este estudio ha sido desarrollado para enriquecer la información médica sobre el accidente de esta serpiente, que a menudo se maneja con dificultades, debido a la ignorancia sobre sus actividades tóxicas. Este trabajo ha estudiado las características bioquímicas y toxinológicas del veneno de P.l.rozei. El objetivo primordial fue determinar sus características bioquímicas, incluida la determinación del contenido de proteínas, el perfil cromatográfico de electroforesis. Las funciones toxinológicas y enzimáticas, comprendieron actividades de letalidad $\left(\mathrm{LD}_{50}\right)$, hemorrágica (MHD), miotóxica, coagulante, proteolítica, fibrinogenolítica, fibrinolítica, anticoagulante y de fosfolipasas, además del reconocimiento del veneno crudo por el antiveneno polivalente venezolano (PAOS). El veneno indujo actividades hemorrágicas, miotóxicas, anticoagulantes, fibrinolíticas, fibrinogenolíticas y de fosfolipasa $\mathrm{A}_{2}$ en ratones; la $\mathrm{DL}_{50}$ no se pudo establecer, a pesar de las dosis probadas. El veneno indujo un edema dependiente de la dosis hasta los $4 \mu \mathrm{g}$, que correspondió al 27,91\%. En conclusión, el veneno estudiado presentó un perfil bioquímico hemostático, toxinológico y enzimático similar al descrito para los especímenes del género Porthidium. Sin embargo, hubo variaciones cuantitativas evidentes en sus diferentes actividades, ofreciendo nueva evidencia de las variaciones intraespecies que existen en las diferentes familias de serpientes. Estas variaciones deben ser detalladas para un manejo clínico apropiado.

Recibido: 17-01-2018 Aceptado:08-08-2018

\section{INTRODUCTION}

The accidents caused by venomous animals of several zoological groups (snakes, scorpions, and spiders), represent a global collective health problem especially associated to the tropical and subtropical zones (1). Venomous ophidic accident, however, is a neglected disease, despite its high incidence and severity, causing permanent functional sequelaes that can progress in affected individuals and their death (2).
Within the most important American snake families, there have been described nine species of the Porthidium genus, which inhabit dry or wooded areas from southern Mexico to north-western South America including Venezuela, Ecuador and Colombia (3). In Venezuela, the Porthidium lansbergii species includes three subspecies: Porthidium lansbergii hutmanni, Porthidium lansbergii lansbergii and Porthidium lansbergii rozei (4, 5). The latter are distributed in the dry and wooded areas of Anzoátegui, Sucre, Bolívar, 
Trujillo, Lara, Falcón, Araǵua, Carabobo and Delta Amacuro states (Venezuela) (6).

A number of reports in the literature have documented different levels of variation in the composition of Porthidium venom $(7,8)$. These differentiations may be related to phylogenetic or taxonomic discrepancies, age, size, geographic location, diet, seasonal variations, variations associated with sex, among others, all these lead to divergences in the quantity and quality of the venoms. The venoms can differ, both at the macro and micro-variable levels, but also can share many components through wide taxonomic levels (9).

Regions with an abundant venomous herpetofauna, as Venezuela, must make efforts to identify snakes causing accidents in cattle and rural human populations. Their venoms must be extensively characterised, identifying the factors involved in the morbidity and mortality of envenomation, with the aim of create guidelines to advance the victim treatments and reinforce the phases of design, production and control of antivenoms, grounded on the accuracy of ophidism in the regions involved (10).

In Venezuela, information related to the Porthidium lansbergii subspecies -widely distributed in the national territory- is scarce. Although it is frequently known by rural doctors - not being a rare envenomingits handling presents difficulties due to the ignorance of its toxic activities. This work has been developed to enrich the medical information of the type of accident. For this reason, in order to expand this knowledge, some biochemical characteristics and biological activities, as well as the recognition of the P. lansbergii rozei (P.l.rozei) venom by Venezuelan polyvalent (PAOS) antivenom serum were studied.

\section{MATERIALS AND METHODS}

\section{Reagents}

Bovine fibrinogen, thrombin and casein, agarose and creatine kinase (CK) determination Kit 520-C (Sigma-Aldrich Chemical Co.,
MO, USA), molecular weight markers for electrophoresis (SDS-PAGE) (Biorad, Philadelphia, USA), plastic Petri dishes (Falcon, USA), polyvalent anti-ophidic serum (PAOS) (Biotecfar S.A, Faculty of Pharmacy of the Central University of Venezuela).

\section{Experimental animals}

White male mice NIH strain, with weights pre-established for each test, purchased from the National Institute of Hygiene "Rafael Rangel" (Caracas, Venezuela) animal facility were used. They were kept in stainless steel cages with hydration and food supply ad libitum.

\section{Ethical statement}

All the experimental procedures related to the use of live animals were carried out by expert personnel, under the pertinent Venezuelan regulations, according to protocols of action approved by Ethical Committee of the Anatomical Institute of the Universidad Central de Venezuela, and the norms for the care and use of animal's laboratory, published by the National Institute of Health (USA) (11).

\section{Snakes and venom}

The P.l.rozei specimens were captured in the surroundings of Cumaná city (Sucre state, Venezuela) (Fig. 1) in "Cerros de Caigüire" which are a physiographic unit located at the North of the city and the East of Manzanares River, from 5 to $160 \mathrm{~m}$ elevation, bordered by a coastal plain that separates the highlands to the south and east of the mentioned hills (12). The ecological area of the snake is located in a bio-region of xerophytic climate, with an average annual temperature of $28^{\circ} \mathrm{C}$, amplitude between the maximum daytime temperature and the minimum nocturnal temperature of 10 to $12^{\circ} \mathrm{C}$ (amplitude of megathermic type), rainfall near $500 \mathrm{~mm}$ annual, with an average relative humidity of $50 \%$ or less. The flora corresponds to typical dry areas of plant formation, such as Opuntia, cactuses, spiny herbs, and trophophilous forests (13). 


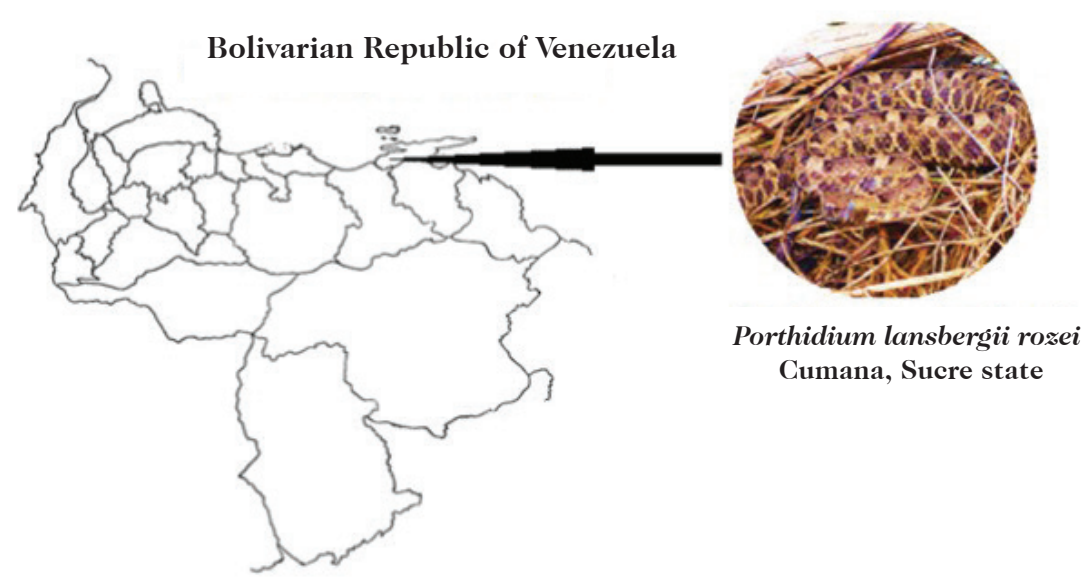

Fig. 1. Geographical location of Porthidium.l.rozei specimen from Cumaná, Sucre state, Venezuela.

Venoms pools from three adult males of mapanare dry-tail (Porthidium lansbergii rozei) (P.l.rozei) were used. The snakes were kept in eaptivity in the Serpentarium of the Tropical Medicine Institute of the Universidad Central de Venezuela (Caracas, Venezuela). After extraction, the venom was centrifuged, lyophilized and stored at $-30^{\circ} \mathrm{C}$.

Porthidium lansbergii hutmanni pool venom used for chromatography was purchased from Bioreptilia C.A (Caracas, Venezuela). This venom was extracted from specimens captured in Margarita Island (Venezuela).

\section{Plasma}

Fresh human plasma was obtained from blood samples of researchers in this work, without alterations in haemostasis or taking anticoagulants. The sample was mixed with $3.8 \%$ sodium citrate in a 9:1 ratio. Plasma was obtained by centrifugation at $2000 \mathrm{rpm}$ for 15 minutes.

\section{Electrophoresis in polyacrylamide gels} (SDS-PAGE) of P.l.rosei crude venom

To establish the electrophoretic profile with $25 \mu \mathrm{g}$ of P.l.rozei venom, 12\% SDS-PAGE was performed using Tris/glycine gels, under reducing and native conditions, following the Laemmli (1970) method (14). Additionally, 10\% Tris/Tricine gels (15) were used to visualise the fibrinogenolytic venom activity. The gels were fixed and stained with silver stain and/or Coomassie blue.

Fractionation of proteins by reverse phase high resolution liquid chromatography

Porthidium. l. rozei and P.l. hutmanni venoms were run in a liquid phase chromatography (RP-HPLC). Briefly, in $200 \mu \mathrm{L}$ [0.1\% trichloroacetic acid (TCA)] solution, $0.34 \mathrm{mg}$ of venom was dissolved and chromatographed on a Simmetry ${ }^{\circledR}$ C-18 column (4.6 $\times 150 \mathrm{~mm})$ using a high resolution chromatography (CLAR) Delta 1525 (Waters, Massachusetts, USA). The elution was carried out at a flow of $1 \mathrm{~mL} / \mathrm{min}$, applying a gradient of solution B (acetonitrile in $0.1 \%$ TCA): $0 \%$ B for $5 \mathrm{~min}, 0$ to $5 \%$ B for $10 \mathrm{~min}$, 15 to $45 \%$ B for $60 \mathrm{~min}, 45$ to $70 \%$ B for 10 min and $70 \% \mathrm{~B}$ for $9 \mathrm{~min}$.

\section{Lethal Activity $\left(\mathrm{LD}_{50}\right)$}

The lethality of P.l.rozei venom was determined by the Spearman-Kärber method (16). Five mice per dose weighing 18-22 g were intraperitoneally injected with $200 \mu \mathrm{L}$ of the serially diluted venom ranging (38.46 and $241.3 \mu \mathrm{g}$ ). Deaths were recorded during a $48 \mathrm{~h}$ period. Mice were observed up to 48 $\mathrm{h}$ after injection. 


\section{Coagulant activity}

To determine the P.l.rozei venom coagulant activity, the method of Austen and Rhymes (17) was used. Bovine fibrinogen was handled as substrates to evaluate the thrombin-like activity, and fresh citrated plasma, to determine the procoagulant activity. Concisely, $0.3 \%$ fibrinogen solution $(100 \mu \mathrm{L})$ diluted in $0.05 \mathrm{M}$ Tris-HCl buffer, $\mathrm{pH} 7.4$ (coagulation buffer) or eitrated plasma was prepared and then incubated for $3 \mathrm{~min}$ at $37^{\circ} \mathrm{C}$. At that point $100 \mu \mathrm{L}$ of coagulation buffer, and $100 \mu \mathrm{L}$ of thrombin solution (2.5 UI / mL) (positive control), or $100 \mu \mathrm{L}$ of crude venom $(1 \mathrm{mg} / \mathrm{mL})$ were added and mixed. Then, the coagulation time at $37^{\circ} \mathrm{C}$ was recorded. The results were expressed in seconds.

\section{Anticoagulant activity}

Aliquots of $0.2 \mathrm{~mL}$ of eitrated human plasma $(3.8 \% \mathrm{v} / \mathrm{v})$ were distributed in glass tubes and incubated in a water bath for 5 min at $37^{\circ} \mathrm{C}$. Then, $50 \mu \mathrm{L}(40 \mu$ g) of P.l.rozei venom was added and further incubated for $10 \mathrm{~min}$ at $37^{\circ} \mathrm{C}$. Finally, $50 \mu \mathrm{L}$ of $0.25 \mathrm{M}$ $\mathrm{CaCl}_{2}$ was added and the coagulation time was determined. The negative control tubes contained plasma incubated only with PBS. The tests were carried out in duplicate and the results were expressed in seconds.

\section{Fibrinogenolytic activity}

The effect of the venom, on the fibrinogen chains using a solution of human fibrinogen $(5 \mathrm{mg} / \mathrm{mL})$ in $0.05 \mathrm{M}$ Tris-HCl buffer, $\mathrm{pH}$ 7.5 was evaluated by fibrinogen (Fg): P.l.rozei

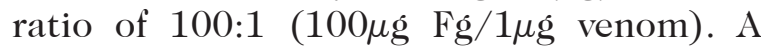
lane control containing only fibrinogen was used for the visualization of the band pattern corresponding to the $\alpha, \beta$ and $\gamma$ chains of fibrinogen. The fibrinogen was incubated for 4 hours, at $37^{\circ} \mathrm{C}$ with the venom, initially in different substrate enzyme ratios, in order to select the appropriate proportion, later evaluating different incubation times, to determine the kinetics chains degradation by means of electrophoresis. Tris-Tricine system
(15) $10 \%$ gels electrophoresis under reduced conditions, visualizing the protein bands with $0.5 \%$ Coomassie blue was performed.

\section{Fibrinolytic activity}

Fibrinolytic activity of P.l.rozei venom was calculated by the fibrin plate method as described by Marsh and Arocha-Piñango (18). Briefly, fibrin plates were prepared using $3-\mathrm{cm}$ diameter Petri dishes: $1.5 \mathrm{~mL}$ of a $0.1 \%$ plasminogen-rich fibrinogen in imidazol saline buffer, pH 7.4 was coagulated by adding $75 \mathrm{~mL}$ bovine thrombin $(10 \mathrm{U} / \mathrm{mL}$, in $\left.0.025 \mathrm{M} \mathrm{CaCl}_{2}\right)$. The mixture was incubated at room temperature for $30 \mathrm{~min}$. Then, 10 $\mu \mathrm{L}$ sample $(1 \mathrm{mg} / \mathrm{mL})$ was applied over the fibrin film, and after $24 \mathrm{~h}$ incubation at $37^{\circ} \mathrm{C}$ the diameter of the lysed areas was measured. Fibrinolytic activity was expressed as the lysed area per microgram of protein $\left(\mathrm{mm}^{2} / \mu \mathrm{g}\right)$. As positive control, $10 \mu \mathrm{L}(1 \mathrm{mg} /$ $\mathrm{mL}$ ) of Bothrops colombiensis crude venom and $12 \mu \mathrm{L}$ of saline solution as negative control were used.

\section{Oedematising activity}

For the activity of oedema formation, the method of Yamakawa et al. (19) was used. A group of five mice, weighing 18-20 gr, were injected into the footpad of the mice right lower limb with venom serial dilutions (2 to $32 \mu \mathrm{g} / 50 \mu \mathrm{L}$ diluted in saline solution). The plantar pad of the left lower limb was injected with $50 \mu \mathrm{L}$ of saline solution; one hour after the injection, the animals were sacrificed by ether inhalation and then both limbs were cut with a scalpel at the tarsal joint level. Both extremities were weighed in the analytical balance, and the oedema was determined, as the percentage of weight increase, in the right extremity with respect to the left. The minimum oedematising dose (MOD) was defined as the least amount of venom producing an oedema higher than $30 \%$ after one hour of exposure. The percentages (\%) of oedema were plotted against the P.l.rozei doses. 


\section{Determination of minimal haemorrhagic dose (MHD)}

To determine the MHD for the P.l.rozei venom, Kondo et al. (20) method was used. Serial venom doses (2.5 to $40 \mu \mathrm{g})$ were dissolved in $100 \mu \mathrm{L}$ of isotonic saline; $0.1 \mathrm{~mL}$ of each dilution was intradermal injected into the depilated abdominal skin of mice. The mouse was sacrificed and the skin removed after $2 \mathrm{~h}$. The haemorrhagic diameter on the skin was measured and the MHD determined. The MHD is defined as the amount of venom protein that causes a $10 \mathrm{~mm}$ haemorrhagic spot, determining the diameter of the developed lesion using the equation:

$$
D=2 \sqrt{\mathrm{A}} / \pi
$$

\section{Caseinolytic activity}

To determine the caseinolytic activity of the P.l.rozei venom, a casein zymography was carried out according to the method of Da Silveira et al. (21). Concisely, $40 \mu$ ǵ Pl.rozei crude venom was diluted in sample buffer (4X) and run on $12 \%$ SDS-polyacrylamide gels, copolymerized with $2 \mathrm{mg} / \mathrm{mL}$ casein, under nonreducing conditions, at $4^{\circ} \mathrm{C}$ and $20 \mathrm{~mA}$. After electrophoresis, the gels were washed twice for 30 min with $2.5 \%$ Triton X-100 to remove the SDS and then incubated in the zymography incubation buffer $(0.05 \mathrm{M}$ Tris- $\mathrm{HCl}, \mathrm{pH} 7.3$, $0.2 \mathrm{M} \mathrm{NaCl}, 0.001 \mathrm{M} \mathrm{CaCl}_{2}, 0.001 \mathrm{M} \mathrm{MgCl}_{2}$ ) at $37^{\circ} \mathrm{C}$ for $18 \mathrm{~h}$. The gels were stained with $0.25 \%$ Coomassie brilliant blue R-250 in acetic acid: ethanol: water solution $(7: 30: 63 \mathrm{v} / \mathrm{v})$ and then kept in the same solution. The presence of caseinolytic activity was defined as light bands on a dark background.

\section{Myotoxic activity}

The ability of the Pl.rozei venom inducing skeletal muscle necrosis was evaluated in mice (18-20 g). A single dose of $40 \mu \mathrm{g} / 50 \mu \mathrm{L}$ of venom was injected into the gastrocnemius muscle. The dose was selected on the basis of previous studies on Viperidae snake venoms (22). As a negative control, the mice received injections of $50 \mu \mathrm{L}$ of saline solution. After 3 hours of injection, blood was collected by cardiac puncture, for enzymatic creatine kinase (CK) serum determination using a commercial kit assay (Sigma Kit 520-C, Sigma Chemical Co.) The CK activity was expressed in international units per litre (IU/L). Once the blood sample was taken, the mice were sacrificed by cervical dislocation, and the extremity inoculated with the studied venom was macroscopically examined, comparing it with the extremity of the negative control mouse.

\section{Zymography of phospholipase A2 (PLA $)$}

In order to identify and estimate the $\mathrm{PLA}_{2} \mathrm{~s}$ molecular weights, a P.l.rozei venom sample using a zymography was analysed. Briefly, the venom sample $(10 \mu \mathrm{g})$ was subjected to a $12 \%$ SDS-PAGE on an under nonreducing conditions, at $60 \mathrm{~V}$ and $4^{\circ} \mathrm{C}$. The gel was washed for 1 hour in $500 \mathrm{mM}$ Tris$\mathrm{HCl}$, pH 7.4, containing 2.0\% (v/v) Triton $\mathrm{X}-100$ and incubated for another hour, in the same solution, but with $1.0 \%$ triton X-100 (v $/ v)$. After removing the SDS residues, the gel was washed a third time for 30 minutes in $50 \mathrm{mM}$ Tris-HCl, $\mathrm{pH} 7.4$, containing 140 $\mathrm{mM} \mathrm{NaCl}$ and $2.5 \mathrm{mM} \mathrm{CaCl}_{2}$. It was then incubated for 14 hours at room temperature on a $1.0 \%(\mathrm{w} / \mathrm{v})$ agarose gel, prepared in 50 mM Tris-HCl, pH 7.4, $140 \mathrm{mM} \mathrm{NaCl,} 2.5 \mathrm{mM}$ $\mathrm{CaCl}_{2}$ and $2.0 \%$ of egg yolk. The light zones indicated the $\mathrm{PLA}_{2}$ presence.

\section{Recognition of the P.l.rosei venom by polyvalent antivenom serum (PAOS)}

The venom toxins identification was carried out by the technique of double immunodiffusion in agarose gels (23) for the detection of anti-P.l.rozei antibodies in the polyvalent antivenom serum (PAOS). This antivenom neutralizes at least $2 \mathrm{mg}$ of bothrophic venom by $1 \mathrm{~mL}$ of serum. Briefly, slides were pre-treated with $1 \%$ agarose and then covered with $3.5 \mathrm{~mL}$ of $2 \%$ agarose. Once the gel was solidified, the wells were drilled equidistant and distributed, one central and 6 peripherals. In the central and 
peripheral wells there were placed $10 \mu \mathrm{L}$ of PAOS and $10 \mu \mathrm{L}$ of $2.5,10$ to $40 \mu \mathrm{g}$ dilutions of P.l.rozei venom, respectively. It was incubated at $37^{\circ} \mathrm{C}$ for 24 hours. Once the precipitation bands were detected, the gel was washed with $0.9 \%$ saline and stained with Coomassie Blue.

\section{RESULTS}

\section{Gel electrophoresis (SDS-PAGE) of P.l.rosei venom}

The 12.0\% SDS-PAGE of P.l.rozei venom was run under reducing and non-reducing conditions. The gel under non-reducing conditions revealed in the first group two (2) bands located between $\sim 66.2$ to $45.0 \mathrm{kDa}$ molecular weights (MW). The second group was between $\sim 45.0$ to $31.0 \mathrm{kDa} \mathrm{MW}$ and had three (3) bands. Under reducing conditions the first group had three (3) bands between $\sim 45.0$ to $31.0 \mathrm{kDa} \mathrm{MW}$, and two bands with lower MW: one (1) band found between 31.0 to $21.5 \mathrm{kDa}$; while the other bands were between MW of 21.5 to $14.4 \mathrm{kDa}$ (Fig. 2).

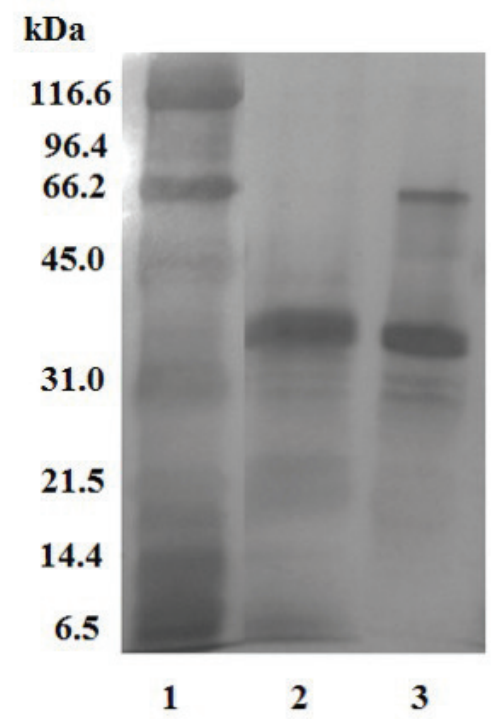

Fig. 2. Electrophoretic profile (SDS-PAGE) under reducing and nonreducing conditions of the $P$. l. rozei venom. 1) molecular weight markers; 2) Porthidium lansbergii rozei venom under reducing conditions; 3) Porthidium lansbergii rozei venom under non-reducing conditions.
Venom fractionation by reverse phase (HPLC)

Fig. 3 shows the comparative chromatograms corresponding to Pl.rozei and P.l.hutmanni venoms run in a Simmetry ${ }^{\circledR}$ C-18 column. There were 28 signals, two of them were very intense and corresponded to 21 and $82 \mathrm{~min}$ in the venom of P.l.rozei. The chromatograms differed mainly in the second intense signal (close to $82 \mathrm{~min}$ ) of $P$. l. hutmanni, and the acetonitrile signal of P.l.rosei at $87 \mathrm{~min}$.

\section{Coagulant activity}

The evaluated bovine fibrinogen and fresh citrated plasma were uncoagulable using $100 \mu \mathrm{g} /$ venom dose; the positive plasma controls gave an average of $19.85 \pm 1.2 \mathrm{~s}$, and the positive control for fibrinogen gave a mean of $18.75 \pm 0.9 \mathrm{~s}$. The results are shown including the mean \pm standard deviation with $\mathrm{n}=5$ (Table I).

\section{Anticoagulant activity}

The P.l.rozei venom in vitro presented anticoagulant activity, showing the fresh citrated plasma uncoagulable at $300 \mathrm{~s}$ with a dose of $40 \mu \mathrm{g}$ of venom. On the other hand, the negative plasma control gave an average of $25.0 \pm 1 \mathrm{~s}$. The results are shown including the mean \pm standard deviation with $\mathrm{n}=$ 5 (Table I).

\section{Fibrinogenolytic activity}

Fig. 4 shows the P.l.rozei venom fibrinogenolytic activity, at a fibrinogen (Fg):

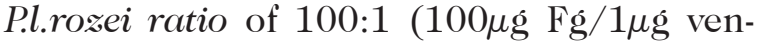
om); whole degradation of the Aa chains as well as soft degradation of the $\mathrm{Bb}$ chains was observed. No apparent alteration to the $\gamma$ chains, even after $24 \mathrm{~h}$ of incubation, was noticed. The degradation of the $\mathrm{A} \alpha$ chains occurred between 1 to $30 \mathrm{~min}$. In contrast, the degradation of the $\mathrm{B} \beta$ chains was between $5 \mathrm{~min}$ to $2 \mathrm{~h}$. This fibrinogenolytic activity was completely inhibited by metalloprotease inhibitor (EDTA), while the serine proteinase inhibitor (trypsin or trypsin-like 

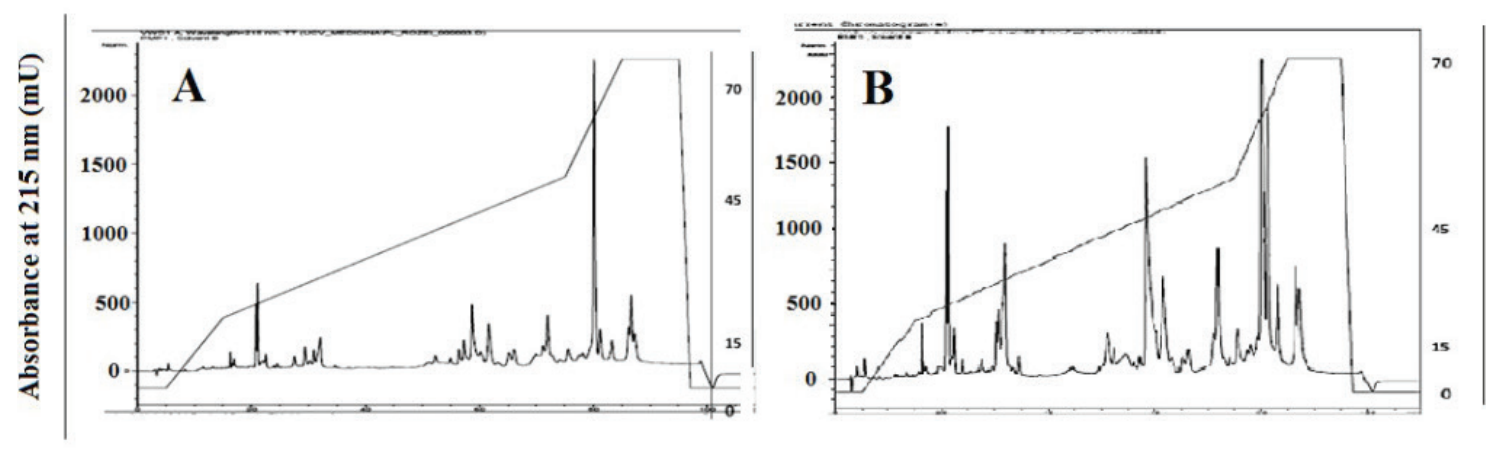

ํㅡㄹ

Time (min)

Fig. 3. Chromatograms of Porthidium l. rozei (A) and P. lansbergii hutmanni (B) venoms $(0.34 \mathrm{mg})$ comparison by Simmetry ${ }^{\circledR}$ C-18 column by reverse phase high resolution liquid chromatography. Elution: Buffer B: 0-70\% in $94 \mathrm{~min}$. Existence of several forms and quantities of proteins in both subspecies has stimulated considerations as possible functional venom differences among them.

TABLE I

COMPARISON OF THE P. lansbergii rozei VENOM (CUMANÁ, SUCRE STATE, VENEZUELA) ENZYMATIC ACTIVITIES WITH DIFFERENT Porthidium VENOM SPECIES PREVIOUS REPORTS

\begin{tabular}{|c|c|c|c|c|c|c|}
\hline Species & $\begin{array}{l}\text { MOD } \\
(\mu g / \\
\text { mouse })\end{array}$ & Coaǵulant & $\begin{array}{l}\text { Anti- } \\
\text { coagulant }\end{array}$ & $\begin{array}{l}\text { Fibrinolytic } \\
\left(\mathrm{mm}^{2} / \mu \mathrm{g}\right)\end{array}$ & $\mathrm{PLA}_{2}$ & References \\
\hline $\begin{array}{l}\text { Porthidium lansbergii hutmanni } \\
\text { (Margarita Island, Venezuela) }\end{array}$ & 1.03 & AA & $\mathrm{NE}$ & 6,8 & $\mathrm{NE}$ & $\begin{array}{l}\text { Girón et al } \\
(2011)^{10}\end{array}$ \\
\hline $\begin{array}{l}\text { Porthidium } \\
\text { lansbergii rozei. } \\
\text { (Falcón state, Venezuela) }\end{array}$ & $\mathrm{NE}$ & $\mathrm{NE}$ & $\mathrm{NE}$ & $\mathrm{NE}$ & $\begin{array}{l}\mathrm{AM} \\
\mathrm{PA}\end{array}$ & $\begin{array}{l}\text { Ramos et al } \\
(2010)^{16}\end{array}$ \\
\hline $\begin{array}{l}\text { Porthidium lansbergii lansbergii } \\
\text { (Atlantic, Colombia) }\end{array}$ & $\mathrm{AM}$ & $\mathrm{AA}$ & $\mathrm{PA}$ & $\mathrm{NE}$ & $\begin{array}{l}\mathrm{AM} \\
\mathrm{PA}\end{array}$ & $\begin{array}{l}\text { Jiménez- } \\
\text { Charris et al } \\
(2015)^{27}\end{array}$ \\
\hline $\begin{array}{l}\text { Porthidium Nasutum } \\
\text { (Antioquia, Colombia) }\end{array}$ & $1.4 \pm 0.1$ & $\mathrm{NE}$ & $\mathrm{NE}$ & $\mathrm{NE}$ & $\mathrm{NE}$ & $\begin{array}{l}\text { Otero et al } \\
(2002)^{46}\end{array}$ \\
\hline $\begin{array}{l}\text { Porthidium nasutum } \\
\text { (Costa Rica) }\end{array}$ & $\mathrm{NE}$ & $\mathrm{AA}$ & $\mathrm{NE}$ & $\mathrm{NE}$ & $\mathrm{NE}$ & $\begin{array}{l}\text { Bogarin et al } \\
\quad(2000)^{45}\end{array}$ \\
\hline $\begin{array}{l}\text { Porthidium } \\
\text { Nasutum } \\
\text { (Costa Rica) }\end{array}$ & $\mathrm{NE}$ & $\mathrm{NE}$ & $\mathrm{NE}$ & $\mathrm{NE}$ & $\begin{array}{l}\mathrm{AM} \\
\mathrm{PA}\end{array}$ & $\begin{array}{l}\text { Gutiérrez } \\
\text { et } a l(2013)^{47}\end{array}$ \\
\hline $\begin{array}{l}\text { Porthidium Ophryomegas } \\
\text { (Pacific/ Costa Rica center) }\end{array}$ & $\mathrm{NE}$ & $\mathrm{NE}$ & $\mathrm{NE}$ & $\mathrm{NE}$ & $\begin{array}{l}\mathrm{AM} \\
\mathrm{PA}\end{array}$ & $\begin{array}{c}\text { Gutiérrez } \\
\text { et al (2013) }\end{array}$ \\
\hline $\begin{array}{l}\text { Porthidium lansbergii hutmanni } \\
\text { (Margarita Island, Venezuela) }\end{array}$ & $\mathrm{NE}$ & $\mathrm{NE}$ & $\mathrm{NE}$ & $\mathrm{NE}$ & $\mathrm{NE}$ & $\begin{array}{l}\text { Pineda et al } \\
(2008)^{26}\end{array}$ \\
\hline $\begin{array}{l}\text { Porthidium lansbergiii rozei } \\
\text { (Sucre state, Venezuela) }\end{array}$ & $\mathrm{AA}$ & $\mathrm{AA}$ & PA & $16.9 \pm 2,8$ & $\mathrm{PA}$ & This study \\
\hline
\end{tabular}

Vol. 59(3): 260 - 277, 2018 
inhibitor benzamidine) had no effect (data not shown). Coagulant activity of fibrinogen (pre-treated with P.l.rozei venom [100:1]) by thrombin resulted in the formation of fine fibrin threads after $280 \mathrm{~s}$. Additionally, fibronectin degradation of fibronectin (a molecule present in the fibrinogen used) can be observed after 5 minutes of incubation. The degradation products are in the molecular mass range of 97.4 and $66.2 \mathrm{KDa}$.

\section{Fibrinolytic activity}

The fibrinolytic activity, determined on fibrin plates and expressed as specific activity $\left(\mathrm{mm}^{2} / \mu \mathrm{g}\right)$, is shown in Fig. 5. It was evident that there was no lysis area in the negative control plate, whereas in the positive control plate the lysis area occupied the entire plate. In the plate with P.l. rozei crude venom, a delimited area of lysis was observed. The fibrinolytic activity of the venom was $16.9 \pm 2.8 \mathrm{~mm}^{2} / \mu \mathrm{g}$. The results are shown including the mean \pm standard deviation with $\mathrm{n}=3$ (Table I).

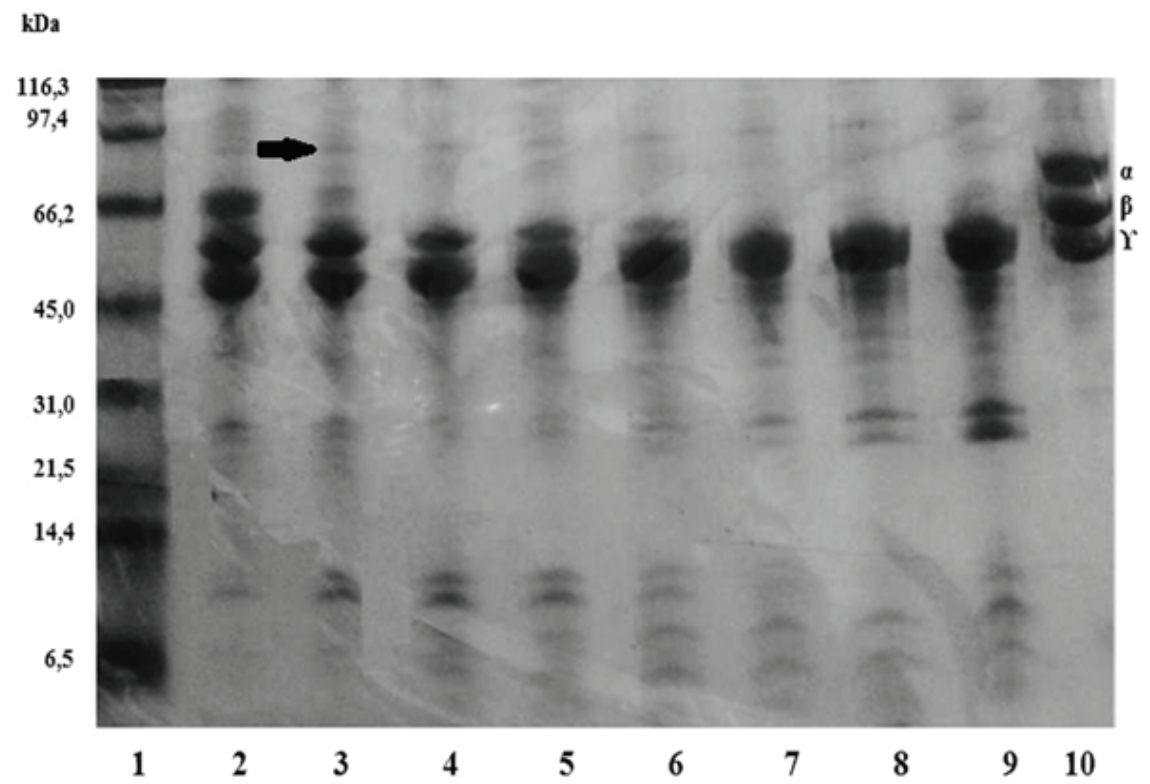

Fig. 4. Fibrinogenolytic 10\% (Tris/Tricine) SDS-PAGE. The fibrinogen was incubated with P.l. rozei, to 100:1 ratio. Lanes 1) molecular weight marker; 2-5) incubation of 1, 5, 15 and 30 min; 6-9): 1, 2, 4 and 24 $\mathrm{h} ; 10)$ control of fibrinogen. The arrow shows products of fibronectin degradation.

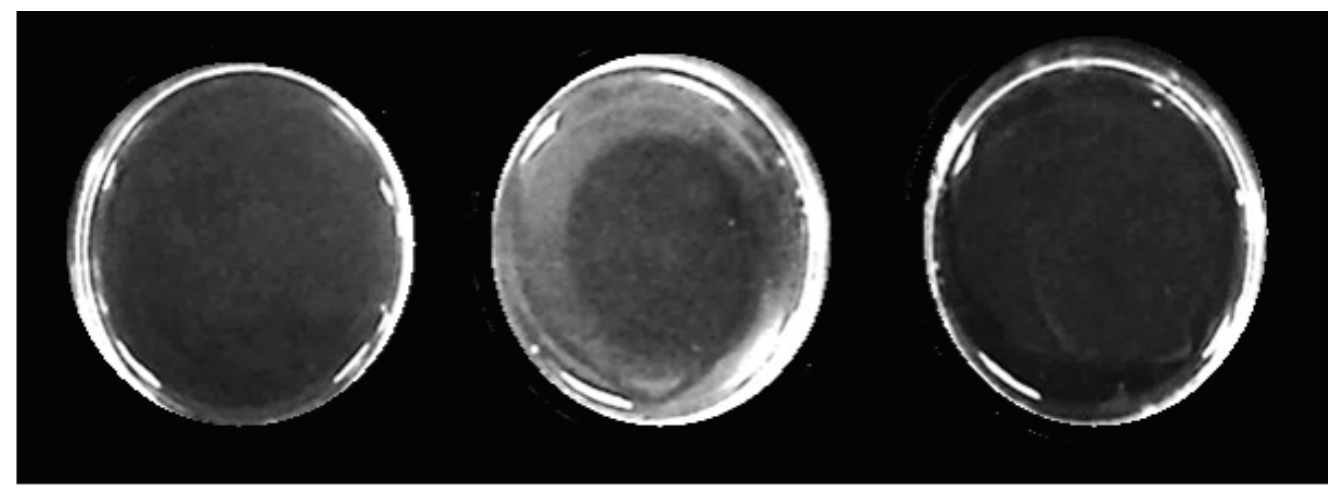

Fig. 5. Fibrinolytic activity of the P.l.rosei venom. Fibrin plates with: A) negative control (0.85\% NaCl solution); B) $10 \mu \mathrm{g}$ of P.l.rozei venom; C) positive control (10 $\mu \mathrm{g}$ of Bothrops colombiensis venom). 


\section{Caseinolytic activity}

The zymogram corresponding to the Pl.rozei venom showed no caseinolytic activity, since no casein digestion bands were observed, in contrast to the $B$. colombiensis venom positive control, in which, at least four clear bands corresponding to the substrate digestion zones could be observed (Fig. 6).

\section{Myotoxic activity}

In the evaluation of the myotoxic activity, an increase of the creatine kinase enzymatic activity was observed. In the negative mouse control, it was $166 \mathrm{U} / \mathrm{L}$ and in those inoculated with $40 \mu \mathrm{g}$ of venom, it was $1555 \pm 572 \mathrm{U} / \mathrm{L}$ (Table II). In addition, macroscopic muscle damage was observed (data not shown).

\section{Zymography of phospholipase $\mathrm{A}_{2}\left(\mathrm{PLA}_{2}\right)$}

In this study, the presence of PLA $\mathrm{Pas}_{2}$ analysed by an egg yolk zymogram. The two venoms tested show clear zones in the region

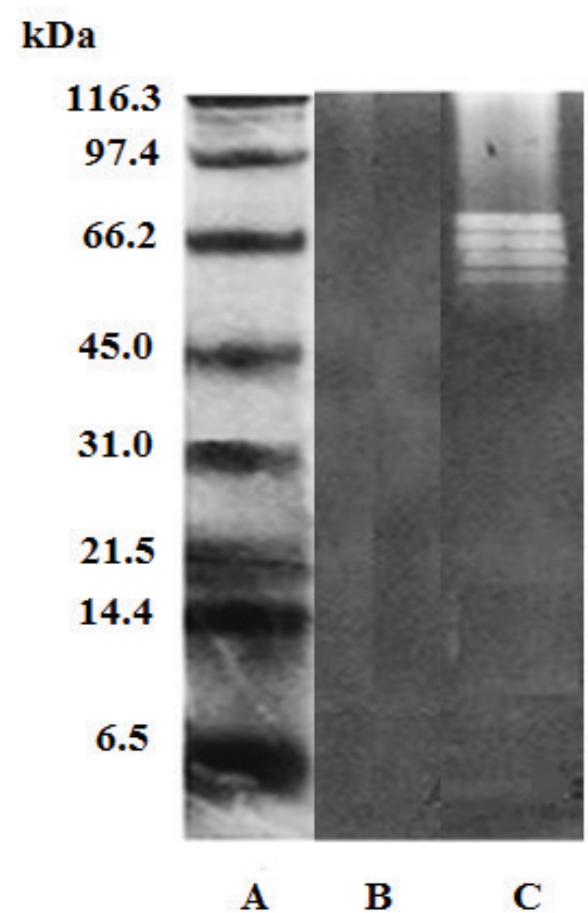

Fig.6. Caseinolytic activity (casein zymogram). A: molecular weiǵht markers; B) P. lansberǵii roæei venom; C) Bothrops colombiensis venom (positive control). near $15 \mathrm{kDa}$. The same amount of venom (10 $\mu \mathrm{g})$ was used in both cases. The B. colombiensis crude venom represented the assay positive control (Fig. 7).

\section{Porthidium.l.rosei venom recognition} by polyvalent antivenom serum (PAOS)

The polyvalent antivenom serum (PAOS) was able to recognize the P.l.rozei venom, which was evidenced as bands of precipitation in the agarose gel (23), denoting the presence of anti-P.l.rozei antibodies in the serum (Fig. 8).

\section{Lethal dose fifty $\left(\mathrm{LD}_{50}\right)$}

Porthidium.l.rozei venom was not lethal to mice at a maximum dose of $241.3 \mu \mathrm{g} /$ mouse, therefore, it was not possible to determine the lethal dose 50. In this group, an animal showed signs of neurotoxicity manifested as paroxysmal tachycardia, tachypnea, tonic-clonic movements and sphineter relaxation. These manifestations lasted seconds and occurred during the first 15 min post inoculation (Table II).

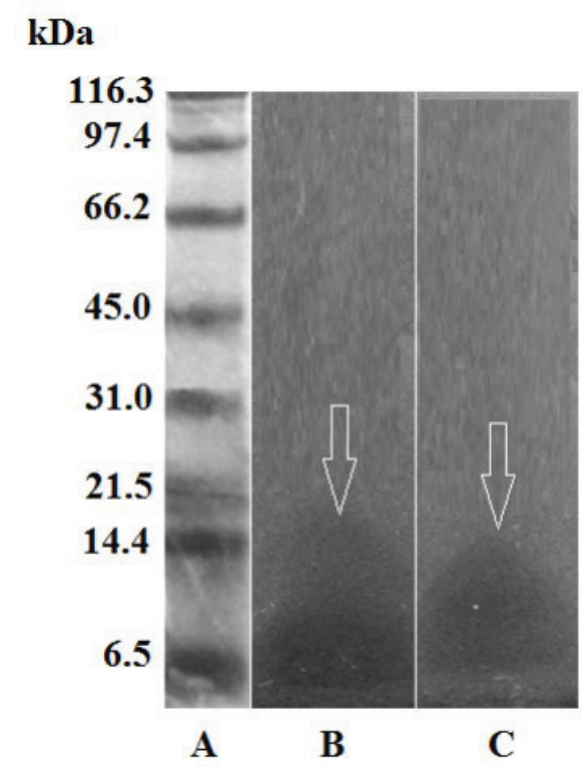

Fig. 7. Phospholipases $A_{2} 12 \%$ SDS-PAGE zymogram on 1\% agarose gel and 2\% eǵg yolk. A) molecular weight markers; B) $10 \mu \mathrm{g}$ of $B$. colombiensis venom; C) $10 \mu \mathrm{g}$ of P.lansbergii roæei venom. 
TABLE II

COMPARISON OF THE TOXINOLOGICAL P.l.rozei (CUMANÁ, SUCRE STATE, VENEZUELA) VENOM ACTIVITIES WITH DIFFERENT Porthidium VENOM SPECIES PREVIOUS REPORTS

\begin{tabular}{|c|c|c|c|c|}
\hline Species & $\begin{array}{c}\mathrm{LD}_{50} \\
(\mu \mathrm{g} / \text { mouse })\end{array}$ & $\begin{array}{c}\text { MHD } \\
(\mu \mathrm{g} / \text { mouse })\end{array}$ & $\begin{array}{l}\text { Myotoxic } \\
\text { CK }(\mathrm{U} / \mathrm{L})\end{array}$ & References \\
\hline $\begin{array}{l}\text { Porthidium lansbergii hutmanni } \\
\text { (Margarita Island, Venezuela) }\end{array}$ & $\begin{array}{c}50 \\
(20-320)\end{array}$ & 0.98 & $\mathrm{NE}$ & Girón et al. (2011) \\
\hline $\begin{array}{l}\text { Porthidium lansbergii rozei. } \\
\text { (Falcón state, Venezuela) }\end{array}$ & $\mathrm{NE}$ & $\mathrm{AM}$ & $\mathrm{AM}$ & Ramos et al. (2010) \\
\hline $\begin{array}{l}\text { Porthidium lansbergii lansbergii } \\
\text { (Atlantic, Colombia) }\end{array}$ & $\begin{array}{c}164 \\
(48-200)\end{array}$ & $\mathrm{AM}$ & $1500-2000$ & $\begin{array}{l}\text { Jiménez- Charris } \\
\text { et al. (2015) }\end{array}$ \\
\hline $\begin{array}{l}\text { Porthidium Nasutum } \\
\text { (Antioquia, Colombia) }\end{array}$ & $\begin{array}{c}109 \\
(82-131)\end{array}$ & $0.96 \pm 0.2$ & $\begin{array}{l}105.000 \pm \\
12.000\end{array}$ & $\begin{array}{l}\text { Otero et al. } \\
\quad(2002)\end{array}$ \\
\hline $\begin{array}{l}\text { Porthidium nasutum } \\
\text { (Costa Rica) }\end{array}$ & 216 & 0.5 & $\mathrm{NE}$ & $\begin{array}{l}\text { Bogarin et al. } \\
\text { (2000) }\end{array}$ \\
\hline $\begin{array}{l}\text { Porthidium Nasutum } \\
\text { (Costa Rica) }\end{array}$ & $\begin{array}{c}178 \\
(149-290)\end{array}$ & $1.6 \pm 0.3$ & $1389 \pm 604$ & $\begin{array}{l}\text { Gutiérrez et al. } \\
\text { (2013) }\end{array}$ \\
\hline $\begin{array}{l}\text { Porthidium Ophryomegas } \\
\text { (Pacific and Costa Rica Center) }\end{array}$ & $\begin{array}{c}149 \\
(117-186)\end{array}$ & $1.1 \pm 0.1$ & $2251 \pm 1330$ & $\begin{array}{l}\text { Gutiérrez et al. } \\
\text { (2013) }\end{array}$ \\
\hline $\begin{array}{l}\text { Porthidium lansbergii hutmanni } \\
\text { (Margarita Island, Venezuela) }\end{array}$ & 94.6 & $25 \pm 0.8$ & $\mathrm{NE}$ & $\begin{array}{l}\text { Pineda et al. } \\
\quad \text { (2008) }\end{array}$ \\
\hline $\begin{array}{l}\text { Porthidium lansbergii rozei } \\
\text { (Sucre state, Venezuela) }\end{array}$ & $\begin{array}{l}\text { Indeterminate } \\
\text { in the used range } \\
\text { (38.46 to } 241.3)\end{array}$ & $13.87 \pm 3.2$ & $1555 \pm 572$ & This study \\
\hline
\end{tabular}

$\mathrm{LD}_{50}$ : Lethal dose fifty; MHD: Minimal haemorrhagic dose; NE: Not evaluated; AM: another methodology.

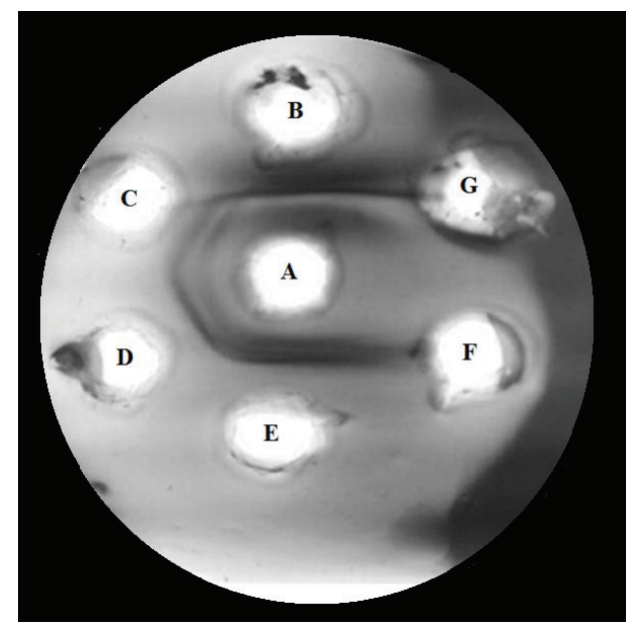

Fig. 8. Recognition of the P.l.rosei venom by the polyvalent antivenom serum (PAOS). A) $10 \mu \mathrm{L}$ of PAOS; B) positive control: B. colombiensis (10 $\mu \mathrm{L} / 40 \mu \mathrm{g})$ venom); C) P.l.rozei $(10 \mu \mathrm{L} / 2.5$ $\mu \mathrm{g})$ venom; D) Pl.rozei $(10 \mu \mathrm{L} / 10 \mu \mathrm{g})$ venom; E) Pl.rozei $(10 \mu \mathrm{L} / 40 \mu \mathrm{g})$ venom F) $10 \mu \mathrm{L}$ of saline solution; G) empty well.

\section{Minimal Haemorrhagic Dose (MHD)}

The MHD for crude venom was 13.87 $\pm 3.20 \mu \mathrm{g} /$ mouse. These lesions increased their intensity and diameter in a dose-dependent manner (Table II).

\section{Oedematising activity}

An oedema developed in the footpad after a subcutaneous injection of P.l.rosei venom, but a minimum oedematogenic dose (30\%), with the increased dose until $4 \mu \mathrm{g}$ was not reached, corresponding to $27.91 \%$ increase in the weight of the inoculated limb. Then, the percentage of induced oedema began to decline. With this dose, it was not possible to determine the minimum oedematising dose (MOD), defined as the amount of venom that produces an oedema of 30\% after one hour of exposure (Table I). In addition, necrosis was observed (data not 
shown), which increased in intensity directly proportional to the increase in the dose (16 $\mu g$ ) of venom evaluated.

\section{DISCUSSION}

Snake bites are of a major collective health importance in Venezuela as a cause of morbidity and mortality. Porthidium $\mathrm{spp}_{\mathrm{s}}$, are responsible for several envenomation cases in East and West Venezuela. Antivenom immunotherapy is the only specific treatment available for envenomed patients. In general, more than 4000 annual patients showed signs of envenomation and were treated with antivenom immunotherapy in the last years, most of them without diagnosis of the species involved in the envenomation. Peasants of both sexes were the most frequently affected. The overall lethality was nearly $2 \%$. Lethality and medical hospitalization were significantly high in the differently treated patients (1).

There are not publications of P.l.rozei clinical cases of envenomation in the country, for which specific clinical information is lacking. The oral communication of rural physicians, who have attended some cases, refer that patients present the appearance of moderate pain at the site of the bite, accompanied by bleeding through the imprint of the fangs, and presence of slight oedema, erythema and generalised ecchymosis covering at least two segments of the affected limb. The patients have successfully responded to the treatment with the polyvalent anti-ophidic serum used in the country (PAOS, Biotecfar, S.A, Venezuela).

According to the current study, the venom of P.l.rozei, a snake geographically located in a neighbourhood of Cumaná, Sucre state, Venezuela (Fig. 1) was able to induce experimental haemorrhagic, myotoxic, anticoagulant, fibrinolytic, fibrinogenolytic, phospholipase $\mathrm{A}_{2}$ activities, aspects that are in agreement with the great majority of snakes that belong to this genus (24). However, there were evident quantitative varia- tions when comparing the results reported in previous evaluations for the same venom snakes (Tables I and II). In the P.l.rozei $\mathrm{LD}_{50}$ venom estimation, limited signs of intoxication in the mice were observed, and none of the different experimental groups died during the time of venom exposure. The doses tested (38.46 to $241.3 \mu \mathrm{g} /$ mouse) include all the $\mathrm{LD}_{50} \mathrm{~s}$ reported in previous studies with Porthidium genus species from different geographical regions. As reported by Girón et al. (8) the $\mathrm{LD}_{50}$ was $50 \mu \mathrm{g}$, while Pineda et al. (7) obtained a $\mathrm{LD}_{50}$ of $94.6 \mu \mathrm{g} /$ mouse for the same species and Jiménez-Charris et al. (25) obtained a $\mathrm{LD}_{50}$ of $164 \mu \mathrm{g} /$ mouse for $P$. langsbergii. Otero et al. (26) reported a $\mathrm{LD}_{50}$ for $P$. nasutum of $109 \mu \mathrm{g} /$ mouse (Table II). These differences among different studies may be due to the intraspecies venom variability with snakes of different origin (27). The results obtained in this research suggest that P.l.rozei is a less potent venom than those evaluated by other authors.

The comparative chromatograms corresponding to P.l.rozei and P.l.hutmanni venoms run in a Simmetry® C-18 column were different in the second intense signal (close to $82 \mathrm{~min}$ ) of $P$. l. hutmanni, and in the acetonitrile signal of P.l.rozei at $87 \mathrm{~min}$. The intra-signal ratio showed that some peptides were found in a greater proportion in P.l.hutmanni, which could result in a greater toxicity of the P.l.hutmanni venom, as compared to the P.l.rozei, due to the larger number of components, probably toxins in that venom. The objective of this comparison was to show that both venoms, from the same genus, are different in their chromatographic profiles and therefore probably in their toxic action. This interspecies venom variability surely originates different clinical manifestations in the envenomed victims.

The haemorrhagic effect is mainly due to the zinc-dependent metalloproteases actions, which function at microvasculature level, destroying the capillary vessels and causing the erythrocytes and plasma exit into the interstitial space, producing selec- 
tive extracellular matrix degradation components, such as different forms of collagen (type IV, type VI, fibrillar, etc.), laminin and fibronectin, these weakens the endothelial basement membrane, followed by its distension and rupture by hemodynamic forces $(28,29)$.

In the haemorrhagic activity evaluation, which is one of the characteristic effects of Porthidium venoms $(7,8,26,30,31)$, it was observed that the P.l.rozei venom exhibits a $13.87 \pm 3.2 \mu \mathrm{g} /$ mouse MHD, which is high when compared with previous reports for this genus (Table II), in which P. l. hutmanni (8) reported a $0.98 \mu \mathrm{g} /$ mouse MHD. Porthidium nasutum from Costa Rica (32) obtained a $0.5 \mu \mathrm{g} /$ mouse MHD, while Gutiérrez et al. (33) reported a $1.6 \mu \mathrm{g} /$ mouse MHD. In Colombia, the same species (26) presented a $0.96 \mu \mathrm{g} /$ mouse MHD. All these data suggest that the venom currently studied has a low haemorrhagic activity as well as a low concentration of metalloprotease-like enzymes, in comparison with these venoms.

On the other hand, when comparing the haemorrhage area obtained with $10 \mu \mathrm{g}$ of the venom under study $\left(68.7 \mathrm{~mm}^{2}\right)$ with P.l. rozei $\left(32.5 \mathrm{~mm}^{2}\right)$ evaluated by Ramos et al. (31), it was evident that P.l.rozei (Cumaná, Sucre state) had higher haemorrhagic action.

Referring to the current P.l.rosei, an increase of CK showed its important myotoxic activity; this result compared with previous Porthidium venom studies (Table II) demonstrated that P.l.lansbergii (25), Porthidium nasutum and Porthidium ophryomegas (33) had the same comportment. Myotoxins and other peptides operating in concert with sodium channels, increasing sodium influx and causing myofibril necrosis are the result of venom toxins (usually basies) action, but sometimes, comprising molecules with acidic phospholipase $\mathrm{A}_{2}$ (34) activity, inducing calcium influx, results in permanent cell damage (35).

In the oedematising activity evaluation using 2 to $32 \mu \mathrm{g}$ doses, after one hour of exposure, there was no $30 \%$ increase of the right extremity with respect to the left (neg- ative control), which did not allow to calculate the MOD. Nevertheless, an oedematising action was observed. It can be deduced that the P.l.rozei venom is not as rich in inflammatory substances, including phospholipases $\mathrm{A}_{2}$ as other Porthidium venoms. The association between oedema and the inflammatory response is obvious and it appears to be species-specific (36). These toxins can induce necrosis, oedema, and inflammation, degrading extracellular matrix components and weakening the regeneration of affected skeletal muscle $(37,38)$.

Additionally, the P.l.rozei venom showed no coagulant activity on fresh citrated plasma or in bovine fibrinogen, which corresponds to the results obtained in previous studies (Table I).

In the evaluation of the anticoagulant activity, the P.l.rozei venom showed this in vitro action on fresh citrated plasma (uncoagulable at $300 \mathrm{~s}$ ). This result was compatible with the one obtained for P. l. lansbergii (25) (Table I). Anticoagulant enzymes including protein $\mathrm{C}$ activators, factor $\mathrm{IX} / \mathrm{X}$, factor $\mathrm{Xa}$ and thrombin inhibitors, phospholipases $\mathrm{A}_{2}$ $\left(\mathrm{PLA}_{2}\right)$ have also been described in snake venoms. These proteases inhibit coagulation by enzymatic or non-enzymatic mechanisms (39). The components responsible for the P.l.rozei venom anticoagulant activity remains to be identified.

In snake venoms there are compounds with the ability to activate the fibrinolytic system, they can be classified as $\alpha$ or $\beta$ fibrinogenases, depending on their activity preferentially on one or another fibrinogen chain, and they belong to both metalloprotease and serine protease enzymes (40). In the present study, the fibrinolytic activity $\left(\mathrm{mm}^{2} /\right.$ $\mu g$ ) was found, that the P.l.rozei venom induced a lysis area larger as the reported for P. l. hutmanni (8) (Table I). This fibrinolytic activity suggests that several venoms contain serine or metalloproteases acting directly on fibrin. These proteases are of great interest since they could have clinical relevance as thrombolytic agents (41). 
Fibrinogen, a dimeric plasma ǵlycoprotein of $340 \mathrm{kDa}$ constituted of six polypeptide chains $(\alpha, \beta, \gamma)$, contributes in the coagulation structure, and is transformed by thrombin to fibrin monomers (49). This protein has been employed for the estimation of the possible fibrinogenolytic influences of natural toxins, and for the confirmation of anticoagulant properties of Viperidae venoms $(27,28)$. A variety of these proteins have been utilised in preclinical medical investigation, to test their probable therapeutic potential as anticoagulants or auxiliary in thrombolytic therapy (51).

Regarding to the fibrinogenolytic activity, the degradation of the fibrinogen chains $(\alpha, \beta$ and $\gamma)$ by the venom of P.l.rozei occurred as follows: the $\alpha$ chain was completely degraded at $30 \mathrm{~min}$, whereas the degradation of the $\beta$ chain was observed at 2 hours. The degradation of $\gamma$ chain by the Pl.rozei venom was not observed. To date there have been only a few reports of fibrinogenolytic enzymes of snake venoms acting on the $\gamma$ chains (42-45).

In addition to the fibrinogen chains degradation, fibronectin degradation was observed. This adhesive protein is a gel band with the highest molecular weight, and its degradation from 5 min of incubation until 24 hours was observed. Lucena et al. (46), by an immunobloting tests, identified this band as contaminating protein in the commercial fibrinogen used in the assays. This activity on fibronectin demonstrates the P.l.rozei venom effects on extracellular matrix components, and therefore, corroborates the presence of metalloproteases in this venom and its haemorrhagic activity.

On the other hand, in the evaluation of the caseinolytic activity, the zymogram corresponding to the P.l.rozei venom did not show casein digestion bands, demonstrating that this venom lacks caseinolytic activity, unlike the B. colombiensis positive control, which had at least four digestion bands corresponding to high molecular weights areas.
Phospholipases (PLA $)$ are calcium-dependent enzymes that eatalyse the hydrolysis of the sn-2 ester bond of phosphoglycerides leading to the formation of free fatty acids and lysophospholipids. In addition to its role in the digestion of prey, their activities is associated with neurotoxicity, myotoxicity, inhibition of coagulation and platelet aggregation, as well as inflammation, hypotension, haemolysis, haemorrhage and contribute to the development of oedema $(33,34)$. Here, regarding the phospholipase $\mathrm{A}_{2}$ activity, clear areas were evident in the agarose-egg yolk gel. The two venoms tested showed clear zones close to $15 \mathrm{kDa}$, which corresponds to the PLA 2 activity on the lecithin present in the gel. Although equal amounts of venom were placed, the light areas patterns with $10 \mu \mathrm{g}$ were different. The B. colombiensis venom presented a greater area, a fact that makes us think that P.l.rozei venom has a lower enzyme concentration or less potent enzymes than the B. colombiensis venom. Phospholipase $\mathrm{A}_{2}$ activity has been reported in other Porthidium species, for instance, the P.l.lansbergii venom (25), besides P.nasutum and P.ophryomegas (33). With respect to the recognition of the P.l.rozei venom by polyvalent antivenom serum (PAOS), the agarose gel double immunodiffusion assays showed precipitation bands or immune complexes, which were observed as a continuous line of immunoprecipitation showing complete identity.

The recognition pattern presented in this work suggests an immunological identity between the components of the P.l.rozei venom and the toxins of Crotalus, Bothrops and P.l. hutmanni.

Finally, in the literature, cases of ophidic accident by Porthidium snakes are limited albeit accidents are not uncommon. Cornejo et al. (49) reported a case produced by P.l. hutmanni, in Nueva Esparta state (Venezuela) with local manifestations that included sudden pain and local bite bleeding, as well as oedema, erythema and burnt sensation. 
In conclusion, P.l.rozei venom has been biochemical and toxinologically studied and the toxinological and enzymatic functions, which included lethality $\left(\mathrm{LD}_{50}\right)$, haemorrhaǵic (MHD), myotoxic, coagulant, oedematising, proteolytic, fibrinogenolytic, fibrinolytic, anticoagulant, phospholiphasic activities and the crude venom recognition by the Venezuelan polyvalent antivenom (PAOS) were described. Here is proposed, according regional physicians that antivenom is a definite, complete, and effective treatment for P.l.rozei envenomations, since administration of PAOS antivenom conduct to ample clinical recuperation, lacking progression to multiple organ dysfunction syndromes. Therefore, antivenom efficiently act toward the acute symptoms and can prevent envenoming development (48).

The venom presented a haemostatic, toxinological and enzymatic biochemical profile comparable to the showed for specimens of the Porthidium genus, although with palpable quantitative disparities in their diverse activities. The diagnosis and treatment of Porthidium bites is on oceasion challenging for clinicians because adequate information has not been offered in clinical practice. There are no fixed diagnostic markers in this practice; therefore, conclusive diagnosis of snake-venom envenoming involves confident identification of the snake and surveillance of the clinical manifestations of envenomation (10).

\section{ACKNOWLEDGEMENTS}

Funding for the project was provided by the Science and Technology Fund (FONACIT) programs) (PEI 201400352, Dr. A. Rodríguez-Acosta, Universidad Central de Venezuela). NIH/ORIP, Viper Resource Grant \#3P40OD010960-10S1, 2P40OD01096011A1, and 5P40OD010960 (NNTRC, Texas A\&M University-Kingsville, Dr. E.E. Sánchez). We would appreciate to thank Mr. Kenji Navarrete-Yoshida for his excellent pho- tographic material, Ms. Ermelinda Morales for her technical assistance and we also like to thank Veronica Rodriguez-Pulido (M.A) for the English correction. The help with the manuscript corrections by two anonymous referees is amply appreciated.

\section{REFERENCES}

1. De Sousa L, Bastouri J, Matos M, Borges A, Bónoli S, Vásquez-Suárez A, Guerrero B, Rodríguez-Acosta A. Epidemiología del ofidismo en Venezuela (1996-2004). Invest Clin 2013; 54: 123 -137.

2. Bagechi S. Experts call for snakebite to be re-established as a neglected tropical disease. BMJ 2015; 351: h5313.

3. Campbell A, Lamar W. The Venomous Reptiles of the Western Hemisphere. Ithaca New York: Cornell University Press; 2004.

4. Lancini A.R. Serpientes de Venezuela. Caracas Venezuela: Editorial Ernesto Armitano; 1970.

5. Flores D, Gregoriani T, Kiriakos D, Cornejo P. Extensión en el rango de distribución de Porthidium lansberǵii rozei Peters 1968 (Toxicofera: Viperidae) para la región nororiental de Venezuela incluyendo datos morfológicos y de historia natural. Saber 2014; 26: 91-96.

6. Navarrete L, López J. Guía de las serpientes de Venezuela Biología venenos conservación y listado de especies. Caracas. Ediciones Bioreptilia; 2009.

7. Pineda M, Girón ME, Estrella A, Sánchez EE, Aguilar I, Fernández I, Vargas AM, Scannone H, Rodríguez-Acosta A. Inhibition of the hemorrhagic and proteolytic activities of Lansberg's hognose pit viper. (Porthidium lansbergii hutmanni) venom by opossum (Didelphis marsupialis) serum: isolation of Didelphis marsupialis $0.15 \mathrm{Dm}$ fraction on DEAE-cellulose chromatography. Immuno Pharmaco Immunotoxicol 2008; 30: 883-896.

8. Girón M, Estrella A, Sánchez EE, Galán J, Tao W, Guerrero B, Salazar AM, Rodríguez-Acosta A. Purification and characterization of a metalloproteinase Porthidin-1 from the venom of Lansberg's hog-nosed pitvipers (Porthidium lansbergii hutmanni). Toxicon 2011; 57: 608-618. 
9. Yarlequé M, Ortiz C, Morante Y, Yarlequé A. Estudio comparativo de algunas propiedades bioquímicas de venenos de serpientes de diferentes regíones del mundo. Soc Quím Perú 2012; 78 27-36.

10. Rengifo C, Rodríguez-Acosta A. Serpientes Veneno y Tratamiento Médico en Venezuela. Universidad Central de Venezuela Caracas: Fondo Editorial de la Facultad de Medicina; 2004.

11. NIH. National Institute of Health. USA: Principles of laboratory animal care Pub. 85: 1-112;1985.

12. Ascanio G. Geología de los cerros de Caigüiré, Cumaná, estado Sucre. IV Congreso Geológiico Venezolano Caracas 1969. Tomo III pp. 1279-1288. 1972.

13. Pifano F. Investigáción y docencia en Medicina Tropical. Arch Ven Med Trop Parasitol Med 1961; 4: 1-203.

14. Laemmli U. Cleavage of structural proteins during the assembly of the head of bacteriophage T-4. Nature 1970; 227: 608-609.

15. Schägiger H, von Jagow G. Tricine-sodium dodecyl sulfate-polyacrylamide gel electrophoresis for the separation of proteins in the range from 1 to $100 \mathrm{kDa}$. Anal Biochem 1987; 166: 368-379.

16. Spearman-Kärber F. Alternative Methods of Analysis for Quantal Responses. In: Statistical Method in Biological Assay. Londres: Finney D.J. Charles Griffin \& Co. Ltd; 1978.

17. Austen D, Rhymes I. A Laboratory Manual of blood coagulation. Oxford London: Osney Mead Blackwell Scientific Publications; 1975.

18. Marsh N, Arocha-Piñango C. Evaluation of the fibrin plate method for estimating plasminogen activator. Thromb Diathes Haemorrh 1972; 28: 75-88.

19. Yamakawa M, Nozaki M, Hokama Z. Fractionation of sakishima-habu (Trimeresurus elegans) venom and lethal hemorrhagic and edema forming activity of the fractions. In: Ohsaka A, Hayashi K, Sawai Y (Ed.). Animal Plant and Microbial Toxins. New York: Plenum Press; 1976.

20. Kondo H, Kondo S, Ikesawa H, Murata R, Oshaka A. Studies on the quantitative method for determination of hemorrhagic activity of Habu snake venom. Jpn J Med Sci Biol 1960; 13: 43-51.
21. Da Silveira RB, dos Santos Filho JF, Mangili OC, Veiga SS, Gremski W, Nader HB, von Dietrich CP. Identification of proteases in the extract of venom glands from brown spiders. Toxicon 2002; 40: 815-822.

22. Pulido-Mendez M, Rodriguez-Acosta A, Finol H, Aguilar I, Girón ME. Ultrastructural pathology in skeletal muscle of mice envenomed with Crotalus vegrandis venom. J Sub Cyt Pathol 1999; 31: 555-561.

23. Ouchterlony O. Antigen-antibody reactions in gels. Acta Pathol Microbiol Scand 1949; 26: 507-515.

24. Boadas J, Matos M, Bónoli S, Borges A, Vásquez A, Serrano L, Quijada N, Villalba R, Pérez Y, Chadee-Burgos R, De Sousa L. Perfil eco-epidemiológico de los accidentes por ofidios en Monagas Venezuela (2002-2006). Bol Mal Sal Amb 2012; 52: 107-120.

25. Jiménez-Charris E, Montealegre-Sanchez L, Solano-Redondo L, Mora-Obando D, Camacho E, Castro-Herrera F, Fierro-Pérez L, Lomonte B. Proteomic and functional analyses of the venom of Porthidium lansbergii lansbergii (Lansberg's hognose viper) from the Atlantic Department of Colombia. J Proteomics 2014; 114: 287-299.

26. Otero R, Núñez V, Barona J, Díaz A, Saldarriaga M. Características bioquímicas y capacidad neutralizante de cuatro antivenenos polivalentes frente a los efectos farmacológicos y enzimáticos del veneno de Bothrops asper y Porthidium nasutum de Antioquia y Chocó. IATREIA 2002; 15 : 5-15.

27. Girón ME, Salazar AM, Aguilar I, Pérez JC, Sánchez EE, Arocha-Piñango CL, Rodríguez-Acosta A, Guerrero B. Hemorrhaǵic coaǵulant and fibrino(geno)lytic activities of crude venom and fractions from mapanare (Bothrops colombiensis) snakes. Comp Biochem Physiol C Toxicol Pharmacol 2008; 147: 113-121.

28. Fox J, Serrano S. Structural considerations of the snake venom metalloproteinases key members of the M12 reprolysin family of metalloproteinases. Toxicon 2005; 45: 969-985.

29. Escalante T, Rucavado A, Fox J, Gutiérrez $\mathbf{J}$. Key events in microvascular damage induced by snake venom hemorrhagic me-

Vol. 59(3): 260 - 277, 2018 
talloproteinases. J Proteomics 2011; 74: 1781-1794.

30. Ramos J, Veliz D, Bremo A, Irausquín J. Efecto de la toxicidad in vivo e in vitro del veneno de Porthidium lansbergii rozei. Comun Salud 2010; 8: 25-31.

31. Lomonte B, Suárez P, Tsai W, Angulo Y, Sasa M, Gutiérrez J, Calvete JJ. Snake venomics of the pit vipers Porthidium nasutum Porthidium ophryomegas and Cerrophidion godmani from Costa Rica: toxicological and taxonomical insiǵhts. Proteomics 2012; 75: 1675-1689.

32. Bogarín G, Morais J, Yamaguchi I, Stephano $\mathrm{M}$, Marcelino $\mathrm{J}$, Nishikawa $\mathrm{A}$, Guidolin R, Rojas G, Higashi HG, Gutiérrez JM. Neutralization of crotaline snake venoms from Central and South America by antivenoms produced in Brazil and Costa Rica. Toxicon 2000; 38: 1429-1241.

33. Gutierrez J, Tsai W, Pla D, Solano G, Lomonte B, Sanz L, Angulo Y, Calvete JJ. Preclinical assessment of a polyspecific antivenom against the venoms of Cerrophidion sasai, Porthidium nasutum and Porthidium ophryomegas: Insights from combined antivenomies and neutralization assays. Toxicon 2013; 64: 60-69.

34. Holzer M, Mackessy SP. An aqueous endpoint assay of snake venom phospholipase A. Toxicon 1996; 34: 1149-1155.

35. Gasanov SE, Dagda RK, Rael ED. Snake venom eytotoxins phospholipase A2s and $\mathrm{Zn} 2+$-dependent metalloproteinases: mechanisms of action and pharmacological relevance. J Clin Toxicol 2014; 4(1): 1000181.

36. de Araújo AL, de Souza AO, da CruzHöfling MA, Flores CA, Bom C. Bothrops lanceolatus (Fer de lance) venom induces oedema formation and increases vascular permeability in the mouse hind paw. Toxicon 2000; 38: 209-221.

37. Amaral CFS, da Silva AO, Godoys P, Miranda D. Renal cortical necrosis following Bothrops jararaca and B. jararacussu snake bite. Toxicon 1985; 23: 877-885.

38. Trebien HÁ, Calixto JB. Pharmacological evaluation of rat paw oedema induced by Bothrops jararaca venom. Agents Actions 1989; 26: 292-300.
39. Sajevic T, Leonardi A, Križaj I. Haemostatically active proteins in snake venoms. Toxicon 2011; 57: 627-645.

40. Markland F. Snake venoms and the hemostatic system. Toxicon 1998; 36:1749-1800.

41. Oyama E, Takahashi H. Structures and functions of snake venom metalloproteinases (SVMP) from Protobothrops venom collected in Japan. Molecules 2017; 22: $1-11$.

42. Serrano SM, Sampaio CA, Mandelbaum FR. Basic proteinases from Bothrops mooje$n i$ (caissaca) venom-II. Isolation of the metalloproteinase MPB. Comparison of the proteolytic activity on natural substrates by MPB MSP 1 and MSP 2. Toxicon 1993; 31: 483-492.

43. Liang XX, Zhou YN, Chen JS, Qiu PX, Chen HZ, Sun HH, Wu YP, Yan GM. Enzymological characterization of FII(a) a fibrinolytic enzyme from Agkistrodon acutus venom. Acta Pharmacol Sin 2005; 26 : 1474-1478.

44. Rodríguez-Acosta A, Sánchez EE, Márquez A, Carvajal $Z$, Salazar A, Girón ME, Estrella A, Gil A, Guerrero B. Hemostatic properties of Venezuelan Bothrops snake venoms with special reference to Bothrops isabelae venom. Toxicon 2010; 56: 926-935.

45. Girón ME, Guerrero B, Salazar AM, Sánchez EE, Alvarez M, Rodríguez-Acosta A. Functional characterization of fibrinolytic metalloproteinases (colombienases) isolated from Bothrops colombiensis venom. Toxicon 2013; 74: 116-126.

46. Lucena S, Guerrero B, Salazar A, Gil A, Arocha-Piñango C. Degradation of extracellular matrix proteins (fibronectin vitronectina and laminin) by serine-proteinases isolated from Lonomia Achelous caterpillar hemolymph. Blood Coagul Fibrinol 2006; 17: 427-435.

47. Cornejo P, De Sousa L, Gregoriani T, Boadas J, Guzmán M, Sánchez D, Valera-Leal J. Primer reporte de envenenamiento humano causado por Porthidium lansbergii hutmanni (Serpentes Viperidae) en la Isla de Coche noreste de Venezuela. Herpetotropicos 2013; 9: 13-18. 
48. Dart RC, MeNally J. Efficacy, safety, and use of snake antivenoms in the United States. Ann Emer Med 2001; 37: 181-188.

49. Monaco S, Gioia M, Rodriguez J, Fasciǵlione GF, Di Pierro D, Lupidi G, Krippahl L, Marini S, Coletta M. Modulation of the proteolytic activity of matrix metalloproteinase-2 (gelatinase A) on fibrinogen. Biochem J 2007; 402: 503-513.
50. Salazar AM, Vivas J, Sánchez EE, Rodríguez-Acosta A, Ibarra C, Gil A, Carvajal Z, Girón ME, Estrella A, Navarrete LF, Guerrero $\mathbf{B}$. Hemostatic and toxinological diversities in venom of Micrurus tener tener, Micrurus fulvius fulvius and Micrurus isozonus coral snakes. Toxicon 2011; 58: 35-45.

51. Swenson S, Markland FS Jr. Snake venom fibrin(ogen)olytic enzymes. Toxicon 2005; 45: 1021-1039. 